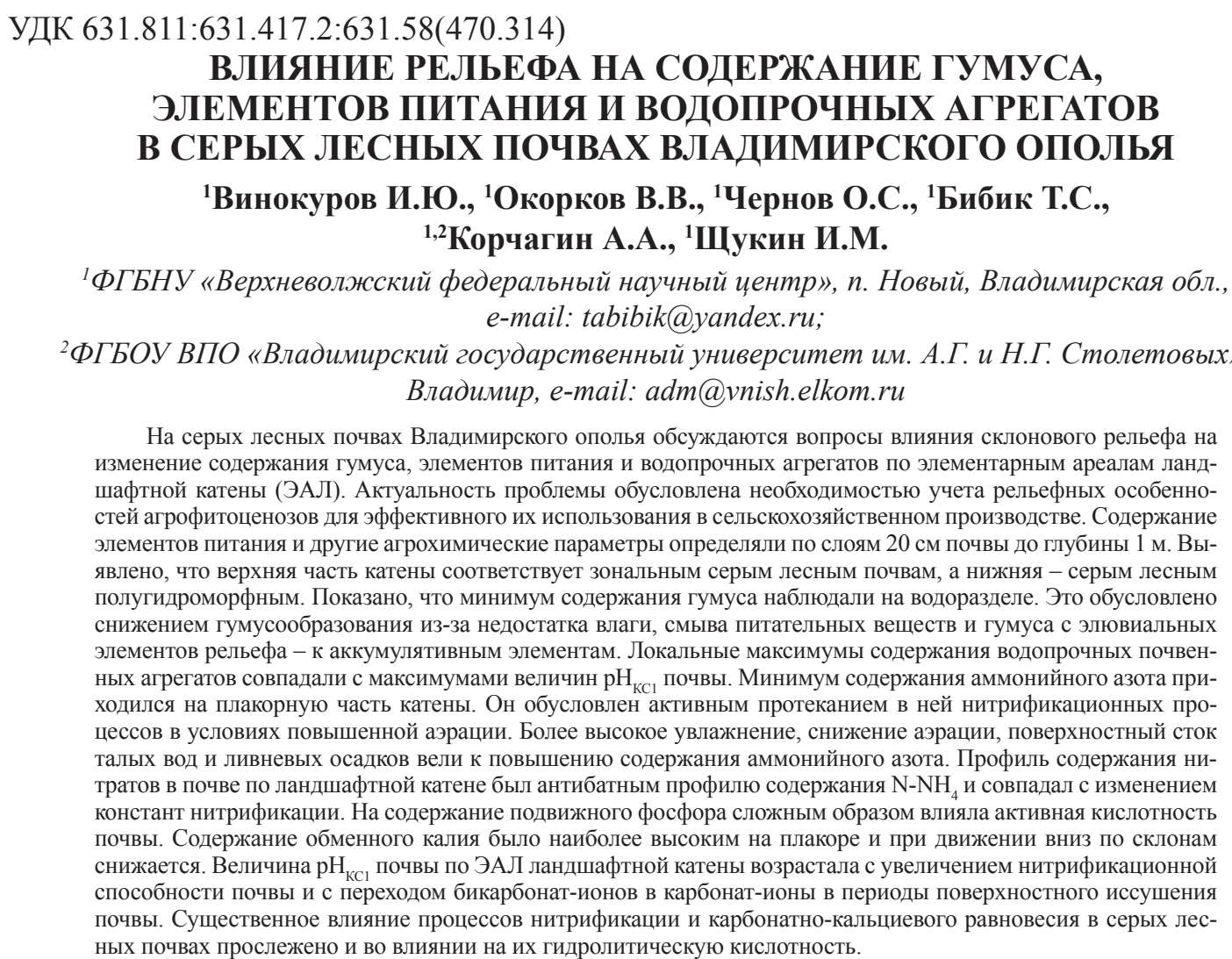

Ключевые слова: ландшафтная катена, рельеф, водопрочные почвенные агрегаты, гумус, элементы питания

\title{
RELIEF IMPACT ON CONTENT OF HUMUS, NUTRIENTS AND WATER STABLE AGGREGATES IN GRAY FOREST SOILS OF VLADIMIR OPOLYE
}

\author{
${ }^{1}$ Vinokurov I.Yu., ${ }^{1}$ Okorkov V.V., ${ }^{1}$ Chernov O.S., ${ }^{1}$ Bibik T.S., \\ ${ }^{1,2}$ Korchagin A.A., ${ }^{1}$ Shchukin I.M.
}

${ }^{1}$ Upper Volga federal Agricultural Scientific Center, Novyi, Vladimir region, e-mail: tabibik@yandex.ru;

${ }^{2}$ Vladimir State University named after A.G. and N.G. Stoletovs, Vladimir, e-mail: adm@vnish.elkom.ru

The questions of slope relief impact on change in the content of humus, nutrients and water-powered aggregates by elementary areas of the landscape catena (EAL) for the gray forest soils of the Vladimir Opolye are discussed. The urgency of the problem is due to the need to consider the relief features of agrophytocenoses for their effective use in agricultural production. The content of nutrients and other agrochemical parameters were determined by layers of $20 \mathrm{~cm}$ of soil to a depth of $1 \mathrm{~m}$. It was revealed that the upper catena part corresponds to zonal gray forest soils, and the lower part - to gray forest semi-hydromorphic ones. It was shown that a minimum of humus content was observed at the watershed. This is due to a decrease in humus formation due to lack of moisture, washing away of nutrients and humus from eluvial relief elements to accumulative elements. The local maxima of the content of water-resistant soil aggregates coincided with the maxima of the soil $\mathrm{pH}_{\mathrm{KCl}}$ values. The minimum content of ammonium nitrogen accounted for the flat part of the catena. It is caused by the active flow of nitrification processes at the conditions of increased aeration. The higher moisture, lower aeration and surface runoff of melt water and heavy rainfall led to an increase in ammonium nitrogen. The profile of nitrates content in the soil in the landscape catena was opposite to the profile of the content of N-NH. This profile coincided with the change of the nitrification constants. The content of mobile phosphorus was influenced by the active acidity of the soil. The content of exchangeable potassium was the highest on the flat part of the catena. The soil $\mathrm{pH}_{\mathrm{KCl}}$ value of the EAL of the landscape catena increased with an increasing of nitrification capacity in the soil and with the transition of bicarbonate ions to carbonate ions during periods of surface soil drying. A significant effect of nitrification processes and carbonate-calcium equilibrium for gray forest soils was also traced for the effect on their hydrolytic acidity.

Keywords: landscape catena, relief, water strong soil aggregates, humus, nutrient elements

Под ландшафтной катеной понимается функционально-динамическое сопряжение природных геосистем, последовательно сменяющих друг друга в направлении от местного водораздела к местному базису эрозии (реке, озеру, оврагу и т.п.). Катенарный ряд географических фаций объединяется в целостную геосистему одно- 
направленным потоком вещества и энергии по склону - сверху вниз. Дифференциация ландшафтов подразумевает рассмотрение ландшафтной катены как дискретной системы. Ее обязательным условием становится выделение элементарных ареалов ландшафта (ЭАЛ) путем разграничений в пространстве [1-3]. В работе [4-5] проведено агроландшафтно-экологическое районирование природных кормовых угодий Центрального федерального округа России и Западной Сибири. Изучалось и влияние уклона местности на развитие корневой системы и эрозию почвы в зависимости от типа землепользования [6].

Дифференциация ландшафтов заложена в исходных условиях катенных исследований. Каждый ЭАЛ находится в границах выдела, внутри которого свойства ареала можно считать изотропными (однородными). В качестве первичной структурной единицы агроландшафта рассматривается элементарный ареал ландшафта, который представляет собой участок на элементе мезорельефа, ограниченный элементарной почвенной структурой, реже - элементарным почвенным ареалом, при одинаковых геологических и микроклиматических условиях [1-3].

Целью исследований стало выявление особенностей распределения элементов питания, гумуса, водопрочных агрегатов по элементарным ареалам ландшафтной катены.

\section{Материалы и методы исследования}

Для исследования распределения элементов питания по элементам ландшафт- ной катены в весенний период полосой в 3,6 м внесены минеральные удобрения $\left(\mathrm{N}_{60} \mathrm{P}_{60} \mathrm{~K}_{60}\right)$. Длина полосы на катене составляет 800 м. На рис. 1 приведен её профиль.

Каждый элементарный ареал ландшафта находится в границах выдела, внутри которого свойства ареала можно считать однородными. Верх катены (ЭАЛ № 4, 5) соответствует зональным серым лесным почвам, низ (ЭАЛ № 2, 3 и ЭАЛ № 6, 7) полугидроморфным серым лесным почвам (с проявлением глеевых процессов). На эти ЭАЛ накладываются дополнительно геохимические различия: элювиальные (верх), аккумулятивные (низ) и транзитные между ними, а также экспозиционные - склоны северо-западной (ЭАЛ № 2, 3) и юго-восточной (ЭАЛ № $6,7,8)$ экспозиции с крутизной, соответственно, 0,86 и $0,97^{\circ}$.

Элементы питания (нитратный и аммонийный азот, фосфор, калий), а также другие агрохимические и агрофизические параметры определяли по слоям 20 см на глубину до 1 м. В почвенных образцах определяли содержание подвижного фосфора по Кирсанову, обменного калия - по Масловой, аммонийного азота - колориметрически по образованию индофеноловой зелени, нитратов - ион-селективным методом; гумуса - по Тюрину, гидролитическую и активную кислотность - по общепринятым методам агрохимического анализа почв. Содержание водопрочных агрегатов устанавливали при мокром просеивании почвенных образцов по Савинову. Погрешность определения указанных параметров не превышала $5 \%$.

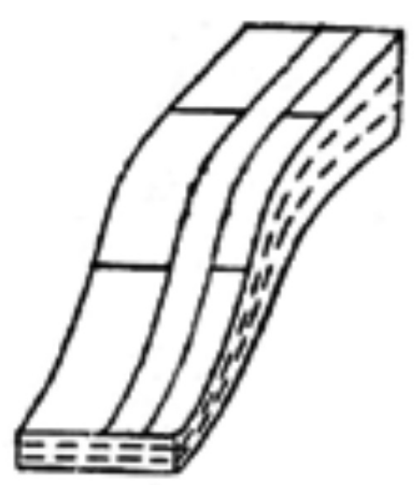

a)

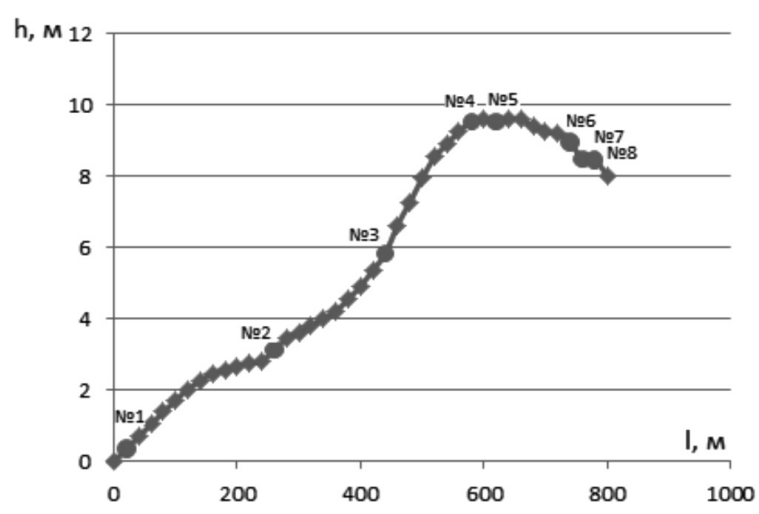

б)

Рис. 1. Форма залегания почв в катенных моделях (а); профиль ландшафтной катень на исследованном агроландшафте (б) 
Константы скорости нитрификации определены из кинетических кривых зависимости концентрации нитратов от времени. В основе их расчета использовалась модель Ферхюльста [7].

\section{Результаты исследования и их обсуждение}

Через транзитные части катены происходит смыв и передвижение питательных веществ и почвенных агрегатов под действием сил гравитации. ЭАЛ № 4 относится к элювиальной области катены, находящейся в центре ландшафта плоской формы, а ЭАЛ № 2 и ЭАЛ № 6, 7 оказываются в аккумулятивных областях катены. Эти особенности проявились на профиле содержания гумуса (рис. 2).

Как видно из рисунка, локальный минимум содержания гумуса относится к водоразделу (ЭАЛ № 4), а абсолютный к ЭАЛ № 1. Первый соответствует более интенсивному испарению влаги, которое приводит к снижению его продуктивности и размеров образования гумуса. Этот процесс усиливается разрушением и смывом водой почвенных агрегатов, гумуса и питательных веществ с элювиальных элементов рельефа через транзитные к аккумулятивным элементам. Судя по низкому содержанию гумуса, ЭАЛ № 1 представляет выположенный эрозионный участок.

Следует принять во внимание, что склон ЮВ экспозиции (ЭАЛ № 5, 6, 7) значительно теплее склона С3 экспозиции (ЭАЛ № 1, $2,3)$, что в весенний период способствовало более раннему началу снеготаяния и усиливало эрозионные процессы. Однако сильные летние ветра северо-западного направ- ления в значительной мере иссушали почву С3 склона (ЭАЛ № 2, 3), чем ЮВ склона. Это обеспечивало более высокие продуктивность и накопление гумуса в ЭАЛ ЮВ экспозиции (ЭАЛ № 6 и 7).

На рис. 3 приведен профиль содержания водопрочных почвенных агрегатов в процентах при исследовании фракционного агрегатного состава почвенных образцов, отобранных с ЭАЛ катены. Видно, что в 2013 г. содержание водопрочных агрегатов в основном более низкое, чем в 2014 г. Это связано с погодными условиями этих лет. В 2013 г. за вегетационный период выпало 431 мм осадков, а в 2014 - 285 мм [8]. Более высокое увлажнение почвы способствовало пептизации почвенных коллоидов и снижению количества водопрочных почвенных агрегатов. Причем локальные максимумы их устойчивости совпадали с максимумами величин $\mathrm{pH}_{\text {кс1 }}$ почвы в слое 0-20 см (рис. 9), за исключением ЭАЛ № 7. В последнем, более теплом ЭАЛ, весной 2013 г. (склон ЮВ экспозиции) более активно протекали эрозионные процессы, вызывая перемещение высокодисперсных частиц на разные расстояния.

В 2014 г. более низкие величины выпадения осадков и гидротермического коэффициента (1,22 в 2014 г. против 1,74 в 2013, [8]) способствовали повышению содержания водопрочных агрегатов. Профиля содержания водопрочных агрегатов в 2013 и 2014 гг. на склоне С3 экспозиции и водоразделе совпадали, на склоне ЮВ - заметно различались. Последнее, возможно, связано с более интенсивным развитием в 2013 г. эрозионных процессов, что повышало варьирование этого параметра.

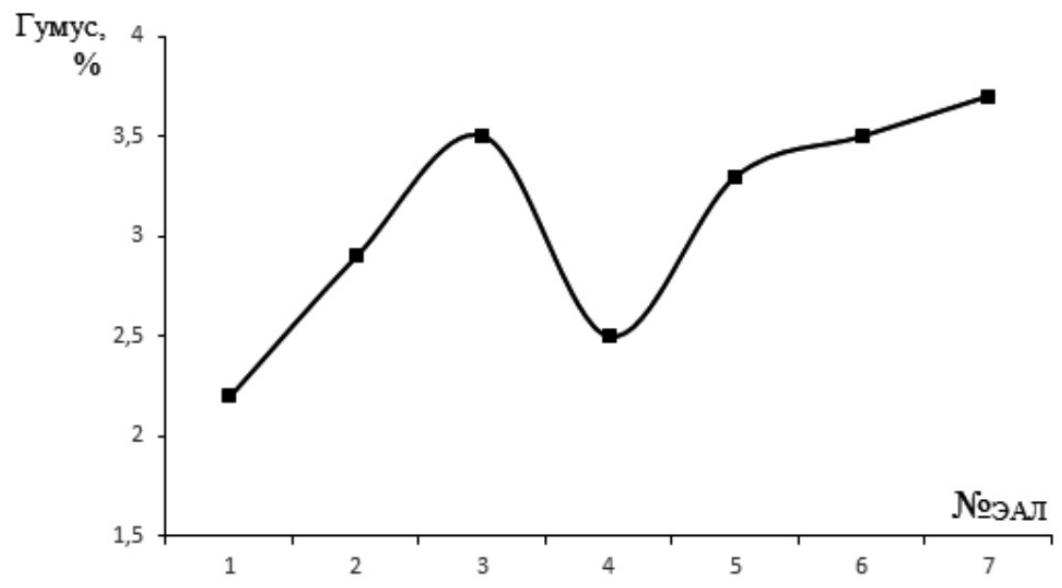

Рис. 2. Изменение содержания гумуса по ЭАЛ ландшафтной катень 


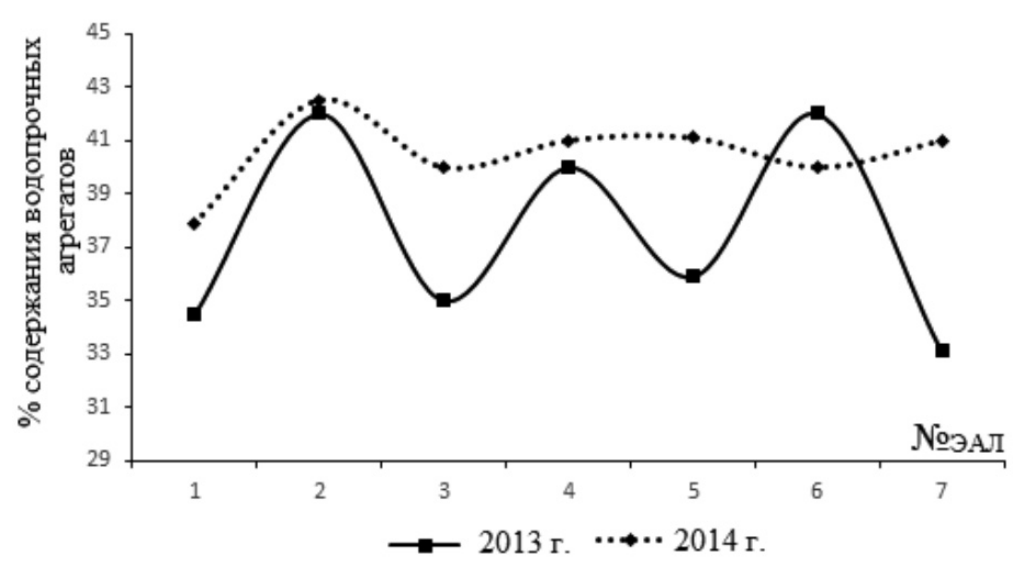

Рис. 3. Профили содержания водопрочных почвенных агрегатов

Более высокое варьирование содержания водопрочных агрегатов на склоновом рельефе по сравнению с плакорными почвами установлено в работе [9]. На плакоре варьирование этого параметра при воздействии различных технологий находилось в пределах $2 \%$, на склоновом рельефе оно достигало $12 \%$ [9].

Профили на рис. 2, 3 соответствуют классическим геохимическим представлениям о движении воды и водных потоков по латеральной кривизне катены и об агрогенно-преобразованных почвах. Специфику их определяет новообразованный поверхностный агрогенно-преобразованный горизонт (АПГ), обычно формирующийся на месте одного или нескольких горизонтов природных почв в результате периодически повторяющихся механических турбаций, как правило, сопровождающихся внесением органических и минеральных удобрений [10].

Колеблющийся характер распределения почвенных агрегатов по ЭАЛ на склоновом рельефе согласуется с соответствующими изменениями продуктивности и профилей биогеохимических параметров, полученных в работе [11] в процессе исследований ландшафтов. Отметим, что их подобие может быть только частным случаем, так как продуктивность (плодородие) почвы определяется разнонаправленным влиянием ряда факторов и условий плодородия почвы [12].

Продуктивность серых лесных почв Ополья в первую очередь определяется запасами (содержанием) нитратного азота в ранний период вегетации культур в слое 0-40 см почвы [12]. Повышают ее и запасы аммонийного азота в этом слое, находящиеся в жидкой фазе почвы [8]. Доля их от запасов аммонийного азота в почве варьировала чаще всего от 10 до $30 \%$. Оптимальное содержание нитратного и аммонийного азота в серой лесной почве можно легко обеспечить применением азотных минеральных удобрений. Рассмотрим влияние расположения ЭАЛ в ландшафтной катене на содержание аммонийного и нитратного азота в почве.

Минимум содержания аммонийного азота в почве (рис. 4) приходился на плакорную часть (ЭАЛ № 1, 4 и 5) катены. Он обусловлен активным протеканием в ней нитрификационных процессов (рис. 5), чему благоприятствовала высокая аэрация этой формы катены. Более высокое увлажнение ЭАЛ № 2 и 3, № 6 и 7 из-за снижения аэрации вело к повышению в них содержания аммонийного азота и уменьшению нитратного азота по сравнению с серыми лесными плакорными почвами. Влияние рельефа на содержание $\mathrm{N}^{-\mathrm{NH}_{4}}$ прослеживалось на большую глубину (до 1 м и более).

Способствовал накоплению аммонийного азота в ЭАЛ № 2 и 3, 6 и 7 и поверхностный сток талых вод и ливневых осадков, с которыми перемещались высокодисперсная минеральная часть почвы с поглощенными ионами аммония и подвижное органические вещество, содержащее азот различных функциональных групп.

Из данных рис. 4 следует, что содержание $\mathrm{N}-\mathrm{NH}_{4}$ по профилю (глубине) отражает его многолетнее накопление, в то время как содержание $\mathrm{N}^{-\mathrm{NO}_{3}}$ (рис. 5) - в основном годовое изменение. В последнем случае содержание $\mathrm{N}-\mathrm{NO}_{3}$ закономерно снижается с глубиной. Это подтверждается и тесной взаимосвязью содержания нитратного азота в слое 0-20 см с константой скорости нитрификации (r) от ЭАЛ катены (рис. 6). 


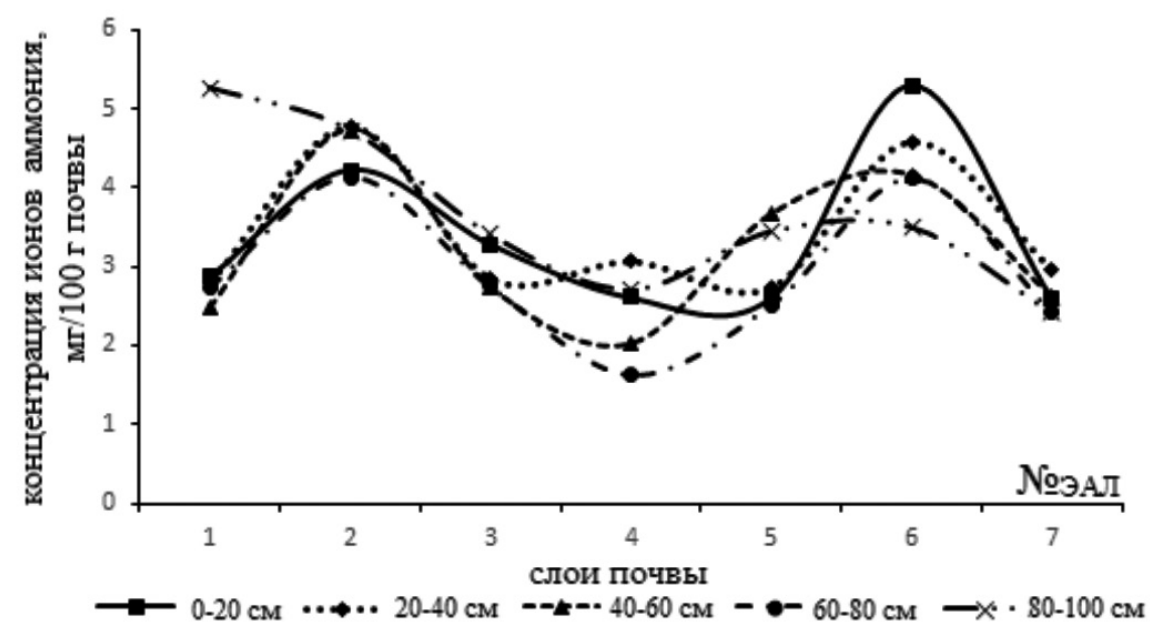

Рис. 4. Изменение концентрации ионов аммония по ЭАЛ ландшафтной катень

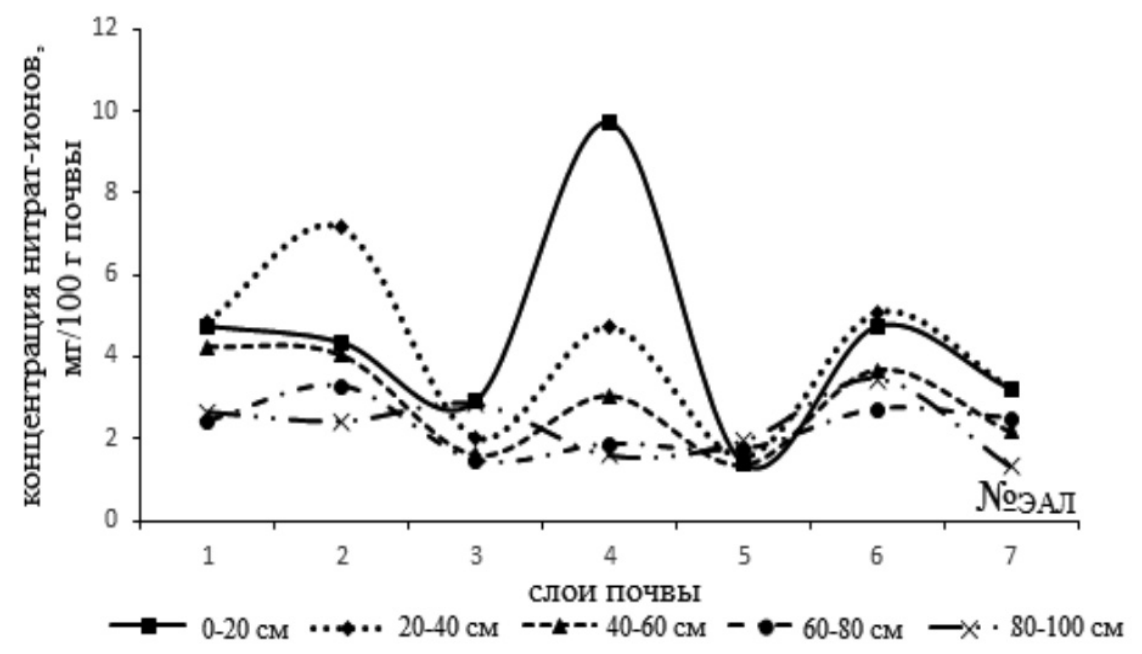

Рис. 5. Изменение концеентрации нитрат-ионов по ЭАЛ ландшафтной катень

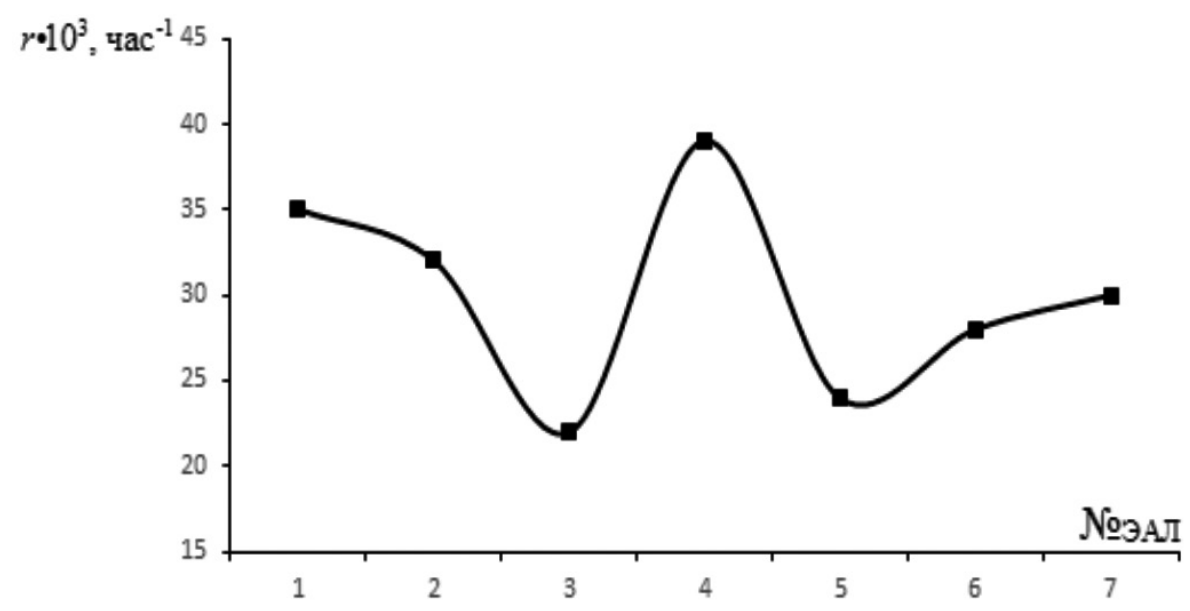

Рис. 6. Изменение константы скорости нитрификащии (r) по ЭАЛ ландмафтной катены

- ADVANCES IN CURRENT NATURAL SCIENCES № 1, 2019 


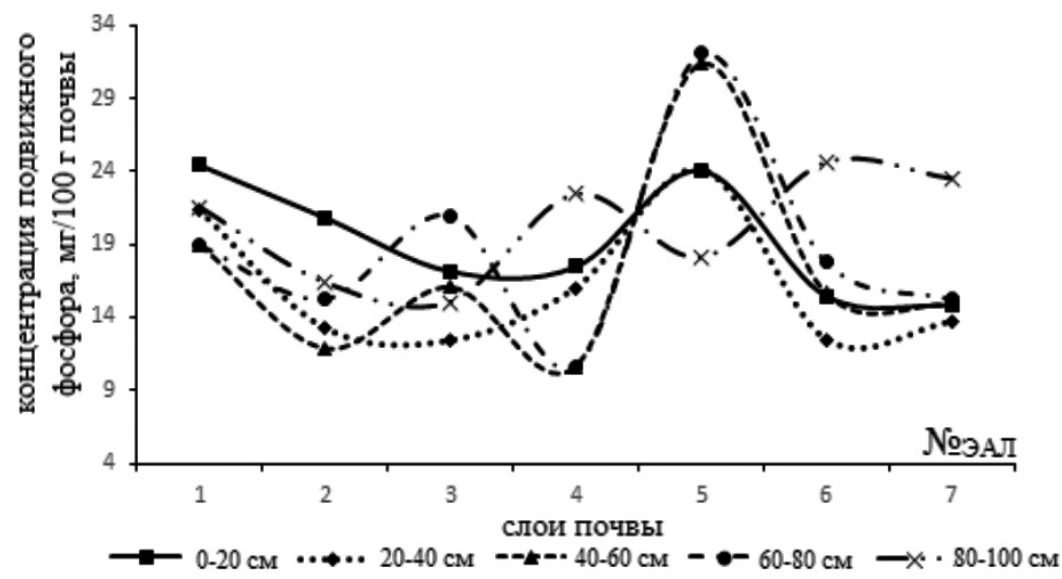

Рис. 7. Изменение концеентрацчии подвижного фосфора $\left(\mathrm{P}_{2} \mathrm{O}_{5}\right)$ по ЭАЛ ландшафтной катень

Фосфор в серых лесных почвах редко находится в 1-м минимуме. Однако при применении азотных удобрений содержание подвижного фосфора может быть недостаточным для получения высоких урожаев возделываемых культур. Из данных рис. 7 следует, что в гумусированном слое 0-20 см содержание подвижного фосфора для всех ЭАЛ высокое $\left(10<\mathrm{P}_{2} \mathrm{O}_{5}<25\right.$ мг/100 г почвы) [12]. Но в то же время для ЭАЛ № 3 и 4, 6 и 7 значения этого параметра варьировали от 15 до 20 мг/100 г почвы, а для ЭАЛ № 1, 2 и 5 - от 20 до 25 мг/100 г почвы.

Из сравнения рис. 7 и 9 следует, что в верхнем слое 0-20 см на содержание подвижного фосфора сильно влияет варьирование $\mathrm{pH}_{\text {Кс1 }}$ почвы. При росте $\mathrm{pH}_{\text {Кс1 }}$ почвы от 5,5 до 5,9 содержание подвижного фосфора слабо изменяется (ЭАЛ № 1, 2 и 5). Отмечается лишь небольшое снижение подвижного фосфора с некоторым снижением $\mathrm{pH}_{\text {кс1 }}$ почвы для ЭАЛ № 3. Однако при $\mathrm{pH}_{\text {кс1 }}$ выше 6 содержание его заметно падает (ЭАЛ № 4, 6 и 7). Максимум содержания подвижного фосфора установлен на ЭАЛ № 5, где $6,0>\mathrm{pH}_{\text {кс1 }}>5,7$.

Для подпахотных слоев с низким содержанием гумуса содержание $\mathrm{P}_{2} \mathrm{O}_{5}$ заметно снижается (ЭАЛ № 2, 3 и 4). Однако в карбонатных слоях $\left(\mathrm{pH}_{\text {кс }}\right.$ выше $6,0)$ на глубине 60-80 и 80-100 см (ЭАЛ № 3 и 4) при растворении основных фосфатов соляной кислотой (в момент определения) содержание подвижного фосфора заметно возрастает. Это установлено и для слоя 80-100 см в 5-7 ЭАЛ. В ЭАЛ № 5 при $\mathrm{pH}_{\text {Кс1 }}$ выше 5,2 в слоях 20-40, 40-60 и 60-80 cM выявлено наиболее высокое содержание подвижного фосфора.

Профиль содержания обменного калия по ЭАЛ катены (рис. 8) сильно отличался от профиля изменения других элементов питания. На водоразделе (ЭАЛ № 4) из-за передвижения влаги от ближайших к склону участков и её испарения наблюдалось наиболее высокое содержание обменного калия. При движении вниз по склону обеих экспозиций содержание этого элемента питания снижалось как под влиянием увеличивающейся инфильтрации влаги, так и делювиальных процессов.

На рис. 9 представлены результаты исследований по изменению активной кислотности почвы по ЭАЛ катены. Видно, что в верхнем 0-20-сантиметровом слое наиболее высокие значения $\mathrm{pH}_{\text {кс1 }}$ почвы (выше 6,5) наблюдаются на ЭАЛ № 4, который соответствует плакору, где наиболее высока нитрификационная активность (рис. 5) и константа скорости нитрификации (рис. 6). Существенная роль нитрат-ионов в повыше-

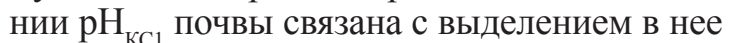
ионов $\mathrm{HCO}_{3}$, подщелачивающих её, в обмен на поглощаемые растениями нитрат-ионы.

На ЭАЛ № 5 со снижением константы скорости нитрификации уменьшаются как содержание нитратного азота (рис. 5), так и величина $\mathrm{pH}_{\mathrm{KC} 1}$ почвы (рис. 9). С ростом константы скорости нитрификации (рис. 6) на теплых склонах ЮВ экспозиции (ЭАЛ № 6 и 7) повышается содержание нитратного азота, величина $\mathrm{pH}_{\text {кс1 }}$ становится выше 6,5. На более холодных ЭАЛ № 1-3 уменьшение нитратного азота приводит к снижению $\mathrm{pH}_{\text {Кс1 }}$ до 5,5-6,0. 


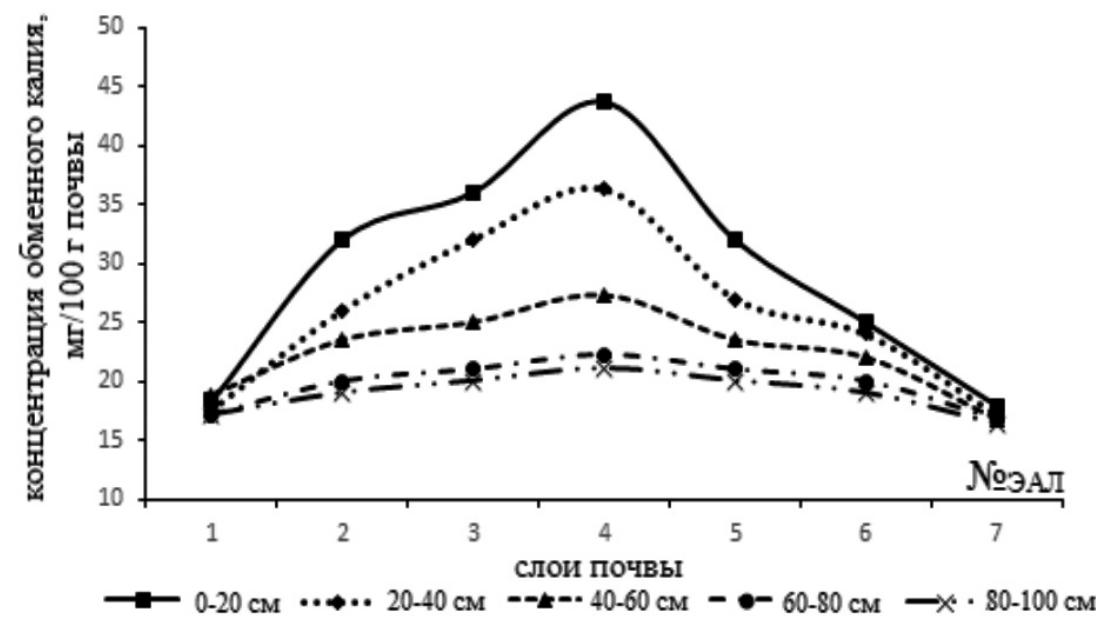

Рис. 8. Изменение концентрации калия $\left(K_{2} O\right)$ по ЭАЛ ландшафтной катень

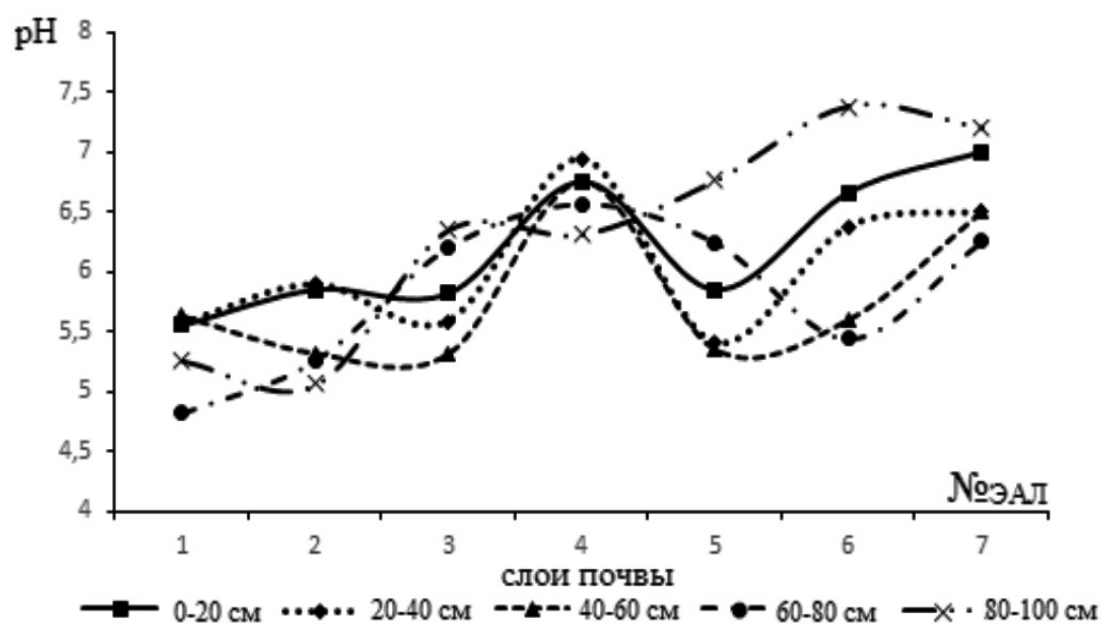

Рис. 9. Изменение величин актуальной кислотности по ЭАЛ ландиафтной катень

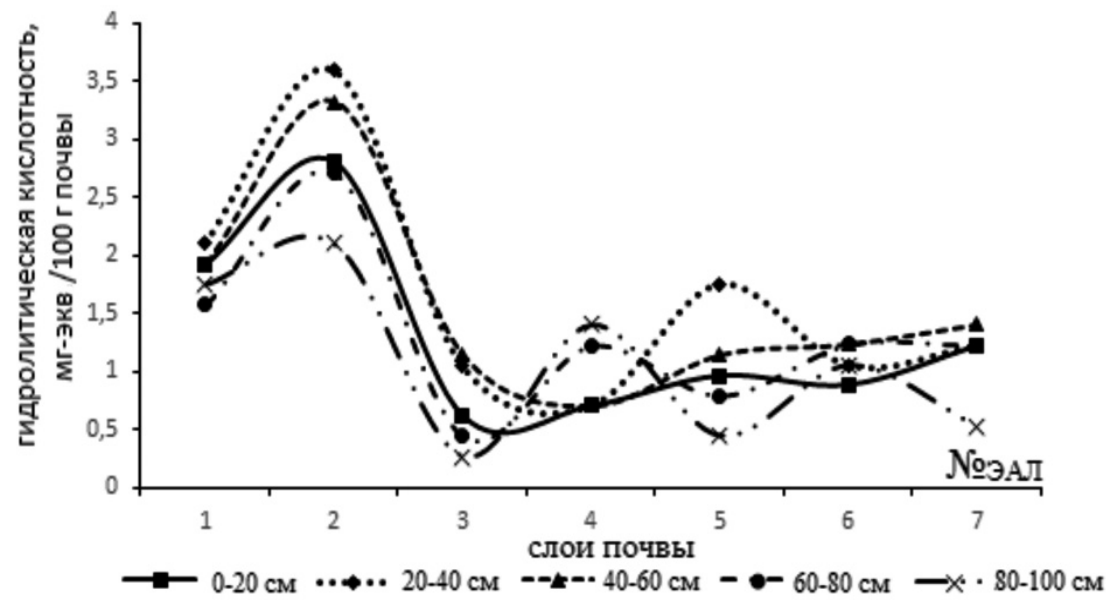

Рис. 10. Изменение величин гидролитической кислотности по ЭАЛ ландшафтной катены 
На хорошо прогреваемом плакоре (ЭАЛ № 4) по всему почвенному профилю метровой глубины величины $\mathrm{pH}_{\text {кс1 }}$ наиболее высокие (выше 6,2). Это связано не только с содержанием нитратного азота, но и с подтягиванием к верхнему горизонту и испарением из него почвенной влаги в засушливые периоды. В этот период происходит превращение $\mathrm{HCO}_{3}^{-}$в $\mathrm{CO}_{3}^{2-}\left(\mathrm{Ca}\left(\mathrm{HCO}_{3}\right)_{2} \rightarrow\right.$ $\mathrm{CaCO}_{3}+\mathrm{CO}_{2} \uparrow$ ), что заметно повышает величину $\mathrm{pH}_{\text {кс1 }}$. Нисходящие и восходящие потоки влаги способствуют выравниванию pН по почвенному профилю.

В ЭАЛ № 6 и 7 величины $\mathrm{pH}_{\text {кс1 }}$ до $80 \mathrm{~cm}$ закономерно снижались с глубиной, что соответствует уменьшению содержания нитрат-ионов с глубиной. В слое 80-100 см почвы наличие карбонатов кальция резко повышает величину $\mathrm{pH}_{\text {кс1 }}$ (до $\mathrm{pH}_{\text {кс1 }} 7,0$ и выше).

В ЭАЛ № 2 и 3 величина $\mathrm{pH}_{\text {КС1 }}$ по сравнению с верхним слоем снижается до 5,15,2 на глубине 60 см. Для ЭАЛ № 3 резкое повышение $\mathrm{pH}_{\mathrm{KC1}}$ на глубине 60-80 и 80100 см обусловлено наличием в них невысоких количеств карбонатов кальция.

Существенная роль процессов нитрификации и карбонатно-кальциевого равновесия в серых лесных почвах Ополья проявляется не только во влиянии на $\mathrm{pH}_{\text {КС1 }}$, но и на гидролитическую кислотность (рис. 10).

Видно, что гидролитическая кислотность в слое 0-20 см почвы наиболее низка (менее 1,2 мг-экв/100 г почвы) на плакоре и склонах ЮВ экспозиции (ЭАЛ № 4-7), то есть на более теплых. Это находится в соответствии с решающей ролью активности нитрификационных процессов на кислотно-основные свойства серых лесных почв Ополья.

В ЭАЛ № 3 гидролитическая кислотность наиболее низкая (около 0,5 мг-экв/100 г почвы), что, по-видимому, обусловлено локальными максимумом содержания гумуса (рис. 2) и минимумом содержания водопрочных агрегатов (рис. 3). По-видимому, в этом ЭАЛ происходило активное взаимодействие гидроксидов железа и алюминия с кислотными группами органического вещества, что заметно снижало отрицательный заряд органоминеральных комплексов и величину гидролитической кислотности почвы.

\section{Заключение}

На серых лесных почвах Владимирского ополья проведены почвенные и геодезические исследования по изменению химических, агрохимических и агрофизических свойств ЭАЛ ландшафтной катены. Установлено, что верхняя часть катены соответствует зональным серым лесным почвам, а нижняя - серым лесным полугидроморфным (с проявлением глеевых процессов). Показано, что минимум содержания гумуса наблюдается на водоразделе. Это обусловлено снижением гумусообразования из-за недостатка влаги, смывом питательных веществ и подвижного гумуса с элювиальных элементов рельефа через транзитные к аккумулятивным элементам. Локальные максимумы содержания водопрочных агрегатов совпадали с максимумами величин

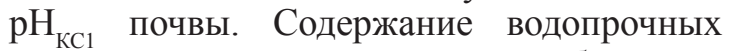
агрегатов в почве повышалось в более теплые и засушливые годы. Минимум содержания аммонийного азота приходился на плакорную часть катены. Он обусловлен активным протеканием в ней нитрификационных процессов в условиях повышенной аэрации. Более высокое увлажнение, снижение аэрации, поверхностный сток талых вод и ливневых осадков вели к повышению содержания аммонийного азота. Профиль содержания нитратов в почве по ландшафтной катене был антибатным профилю содержания $\mathrm{N}-\mathrm{NH}_{4}$ и совпадал с изменением констант нитрификации. На содержание подвижного фосфора сложным образом влияла активная кислотность почвы. Содержание обменного калия было наиболее высоким на плакоре из-за передвижения влаги от ближайших к склону участков и её испарения. При движении вниз по склону обеих экспозиций содержание $\mathrm{K}_{2} \mathrm{O}$ снижалось как под влиянием увеличивающейся инфильтрации влаги, так и делювиальных процессов.

Величина $\mathrm{pH}_{\mathrm{KC1}}$ почвы по ЭАЛ ландшафтной катены возрастала с увеличением нитрификационной способности почвы и с переходом бикарбонат-ионов в карбонатионы в периоды поверхностного иссушения почвы. В глубоких слоях она возрастала при наличии карбонатов кальция. Существенное влияние процессов нитрификации и карбонатно-кальциевого равновесия в серых лесных почвах Ополья прослежено и во влиянии на их гидролитическую кислотность.

\section{Список литературы / References}

1. Кирюшин В.И. Теория адаптивно-ландшафтного земледелия и проектирование агроландшафтов. М.: Колос, 2011. 442 c.

Kiryushin V.I. The theory of adaptive-landscape agriculture and design of agricultural landscapes. M.: Kolos, 2011. 442 p. (in Russian). 
2. Кирюшин В.И., Иванов А.Л. Состояние и перспективы освоения агротехнологий // Агробизнес. Современные стратегии, технологии, менеджмент. 2008. № 1. С. 13.

Kiryushin V.I., Ivanov A.L. The State and prospects of development of agricultural technologies // Agribusiness. Modern strategies, technologies, management. 2008. № 1. P. 13 (in Russian).

3. Кирюшин В.И. Развитие территориального планирования на ландшафтно-экологической основе // Агроэкология. 2015. № 1. С. 4-9.

Kiryushin V.I. Development of territorial planning on the landscape-ecological basis. // Agroecology. 2015. № 1. P. 4-9 (in Russian).

4. Добротворская Н.И. Агроэкологические особенности проектирования адаптивно-ландшафтных систем земледелия в Западной Сибири // Известия Оренбургского государственного аграрного университета. 2018. № 5 (73). C. 27-30.

Dobrotvorskaya N.I. Agroecological features of design of adaptive-landscape systems of agriculture in Western Siberia // Izvestiya Orenburg State Agrarian University. 2018. № 5 (73). P. 27-30 (in Russian).

5. Трофимов И.А., Трофимова Л.С., Яковлева Е.П Агроландшафтный подход к сохранению плодородия почв Центрального федерального округа России // Плодородие. 2018. № 3 (102). C. 14-17.

Trofimov I.A., Trofimova L.S., Yakovleva E.P. Agrolandscape approach to preservation of soil fertility of the Central Federal District of Russia // Plodorodie. 2018. № 3 (102). P. 14-17 (in Russian).

6. Гочияева 3.У., Гедиев К.Т., Токова Ф.М. Влияние уклона местности на развитие корневой системы и эрозию почвы в зависимости от типа землепользования // Успехи современного естествознания. 2018. № 5. С. 33-39.

Gochiyayeva Z.U., Gediev K.T., Tokova F.M. The influence of slope for root system development and soil erosion depending for type land use // Advances in current natural sciences. 2018. № 5. P. 33-39 (in Russian).

7. Винокуров И.Ю. Стабильность и устойчивость агроэкосистем: Системный и системно-структурный подходы.
LAP LAMBERT Academic Publishing Gmbh \& Co, KG, Saabrucken, Germany, 2014. 144 p

Vinokurov I.Yu., Stability and sustainability of agroecosystems: Systematic and systemic-structural approaches. LAP LAMBERT Academic Publishing Gmbh \& Co, KG, Saabrucken, Germany, 2014. 144 p. (in Russian).

8. Окорков В.В., Фенова О.А., Окоркова Л.А. Приемы комплексного использования средств химизации в севообороте на серых лесных почвах Верхневолжья в агротехнологиях различной интенсивности. Суздаль: ФГБНУ «Владимирский НИИСХ», 2017. 176 с.

Okorokov V.V., Fenova O.A., Okorkova L.A. The Methods of complex use of chemicals in crop rotation for grey forest soils of the upper Volga region in the agricultural technologies of varying intensity. Suzdal: FGBNU «Vladimirskij NIISX», 2017. 176 p. (in Russian).

9. Винокуров И.Ю., Чернов О.С., Корчагин А.А. Вторичная сукцессия агрогенно-преобразованных серых лесных почв // Владимирский земледелец. 2016. № 2 (76). С. 2-5.

Vinokurov I.Yu., Chernov O.S., Korchagin A.A. Secondary succession agrogene-converted gray forest soils // Vladimirskij zemledelecz. 2016. № 2 (76). Р. 2-5 (in Russian).

10. Лебедева И.И., Тонконогов В.Д., Шишов Л.Л. Агрогенно-преобразованные почвы: эволюция и систематика // Почвоведение. 1996. № 3. С. 351-358.

Lebedeva I.I., Tonkonogov V.D., Shishov L.L. Agrogene transformed soils: evolution and taxonomy // Soil science. 1996. № 3. P. 351-358 (in Russian).

11. Винокуров И.Ю. Системно-структурный подход к управлению ландшафтами // Проблемы региональной экологии. 2013. № 1. С. 27-32.

Vinokurov I.Yu. The structural approach to landscape management// Problems of regional ecology. 2013. № 1. P. 27-32. (in Russian)

12. Сафонов А.Ф., Гатаулин А.М., Платонов И.Г. Системы земледелия / Под ред. А.Ф. Сафонова. М.: Колос, 2009. 447 с.

Safonov A.F., Gataulin A.M., Platonov I.G. Farming systems / Under the editorship of A.F. Safono. M.: Kolos, 2009. 447 p. (in Russian). 